\title{
Fundamentals of Brain Tumor Surgery in Eloquent Areas
}

\section{Fundamentos da cirurgia de tumor cerebral em áreas eloquentes}

\author{
José Marcus Rotta ${ }^{1}$ Matheus Fernandes de Oliveira ${ }^{1}$ \\ ${ }^{1}$ Department of Neurosurgery, Hospital do Servidor Público Estadual \\ de São Paulo, São Paulo, Brazil \\ Address for correspondence Matheus Fernandes de Oliveira, MSc, \\ Rua Pedro de Toledo 1800, Vila Clementino, São Paulo, SP, Brazil, CEP \\ Arq Bras Neurocir 2015;34:122-127. \\ 04039-004 (e-mail: mafernoliv@yahoo.com.br).
}

\begin{abstract}
Keywords

- brain cortex

- brain tumor

- surgery

\section{Resumo}

\section{Palavras-chave}

- córtex cerebral

- tumor cerebral

- cirurgia

Central nervous system tumors are a major cause of morbidity and mortality. The main pathology involved is brain metastases, followed by intrinsic gliomas. In nearly all cases, surgery is the initial and most important measure to change natural course of disease. In brain metastases and meningiomas, gross total resection is also precluded, and usually more achievable, because of biological behavior of tumor and extrinsic presentation. Generally these tumors push or compress eloquent areas, but spare them. In intrinsic tumors, complete resection is often difficult, once tumor is invasive and may even be within eloquent cortex. When tumors occur in eloquent areas such as sensorial, motor and language cortex, there is the need for taking several measures to avoid worsening of symptoms after surgery. Especially in lesions involving language cortex, an awake craniotomy may be performed to assess intraoperatively language functions.

Tumores no Sistema nervosa central são a maior causa de morbimortalidade. A principal patologia é metástase do cérebro, seguida de gliomas intrínsecos. Em quase todos os casos, cirurgia é a primeira e mais importante medida para impedir a evolução da doença. Em metástase do cérebro e meningiomas, ressecção brutal total é igualmente excluída e geralmente mais factível, devido ao comportamento biológico do tumor e apresentação extrínseca. Normalmente, estes tumores empurram ou comprimem áreas eloquentes, mas o separam. Em tumores intrínsecos, a ressecção completa é difícil, uma vez que o tumor é invasivo e pode até mesmo estar dentro córtex. Quando tumores ocorrem em áreas eloquentes, como a sensorial, a motora e o córtex de linguagem, há a necessidade de tomar diversas medidas para evitar piora dos sintomas pós-cirúrgicos. Particularmente em lesões envolvendo o córtex da linguagem, uma craniotomia desperta deve ser realizada para acesso funções linguísticas de forma intraoperativa.
\end{abstract}

received

August 18, 2014

accepted

March 31, 2015
DOI http://dx.doi.org/

$10.1055 / \mathrm{s}-0035-1554740$. ISSN 0103-5355.
Copyright $(2015$ by Thieme Publicações License terms Ltda, Rio de Janeiro, Brazil
(®) $\Theta \circledast$ 


\section{Introduction}

Central nervous system tumors are a major cause of morbidity and mortality. The main pathology involved is brain metastases, followed by intrinsic gliomas. In nearly all cases, surgery is the initial and most important measure to change natural course of disease. ${ }^{1-4}$

The optimal treatment of low-grade gliomas (LGG) remains controversial. Guidelines on the early management of young patients presenting with seizures only and a lesion compatible with an LGG is not based on solid clinical evidence. Options vary from conservative treatment, surgery alone, adjuvant therapy alone, and surgery plus adjuvant therapy. In high-grade gliomas (HGG), early management with radical surgery and adjuvant chemotherapy and radiotherapy are the standard protocol. With rising advances in chemical components of chemotherapy agents, there is a wide border to the development of new agents with metabolic targets and molecular therapy. Additionally, new strategies for radiotherapy allow less side effects and better results. $^{5-9}$

In brain metastases and meningiomas, gross total resection is also precluded, and usually more achievable, because of biological behavior of tumor and extrinsic presentation. Generally these tumors push or compress eloquent areas, but spare them. In intrinsic tumors, complete resection is often difficult, once tumor is invasive and may even be within eloquent cortex. $^{10-13}$

Objectives of tumor surgery include maximal resection of neoplastic tissue and minimal risk of functional neurologic deficit. A well-performed surgery will validate all subsequent strategies, increasing response to chemotherapy and radiotherapy, when necessary. Surgical act involves a complex structure, which demands planning, knowledge of cerebral anatomy, and physiology and technical execution. ${ }^{11,14-18}$

When tumors occur in eloquent areas such as sensorial, motor, and language cortex, there is the need for taking several measures to avoid worsening of symptoms after surgery. Especially in lesions involving language cortex, an awake craniotomy may be performed to assess intraoperatively language functions. ${ }^{1-4}$

In this brief essay, we summarize current basis for brain tumor surgery in eloquent areas.

\section{Treatment Protocol}

\section{Preoperative Assessment}

Previously to surgery, there is need to comprehend patient and family fears and expectations. A narrow relationship between treatment team and patient is the best tool toward positive results. A multidisciplinary treatment must be used. The neurosurgeon is usually the leader; however, a team composed of phonoaudiologist, physiotherapist, neurologist, and intensive care physicians is crucial for the final result.

Clinical conditions previous to surgery must be addressed to avoid intraoperative complications. Image evaluation must include computed tomography (CT) and magnetic resonance (MR). It is important to evaluate flair, T2, and gadolinium-enhanced images, determining precise anatomical location, tumor shape and size, infiltration pattern, involvement of functional areas, evaluation of spectroscopy, and perfusion. There is also the need to evaluate accessibility of tumor.

To avoid complications, methods of motor and language mapping are becoming increasingly accurate and useful. These can be noninvasive and invasive. Preoperative and noninvasive methods include functional magnetic resonance imaging (MRI), transcranial magnetic stimulation (TMS), and tractography.

Functional MRI defines anatomical basis for sensorial and motor cortex, being interesting to evaluate if eloquent cortex is within lesion, preserved or dislocated due to tumoral compression (-Fig. 1). Functional MRI also allows preoperative assessment and characterization of eloquent cortex

\section{Functional MRI}

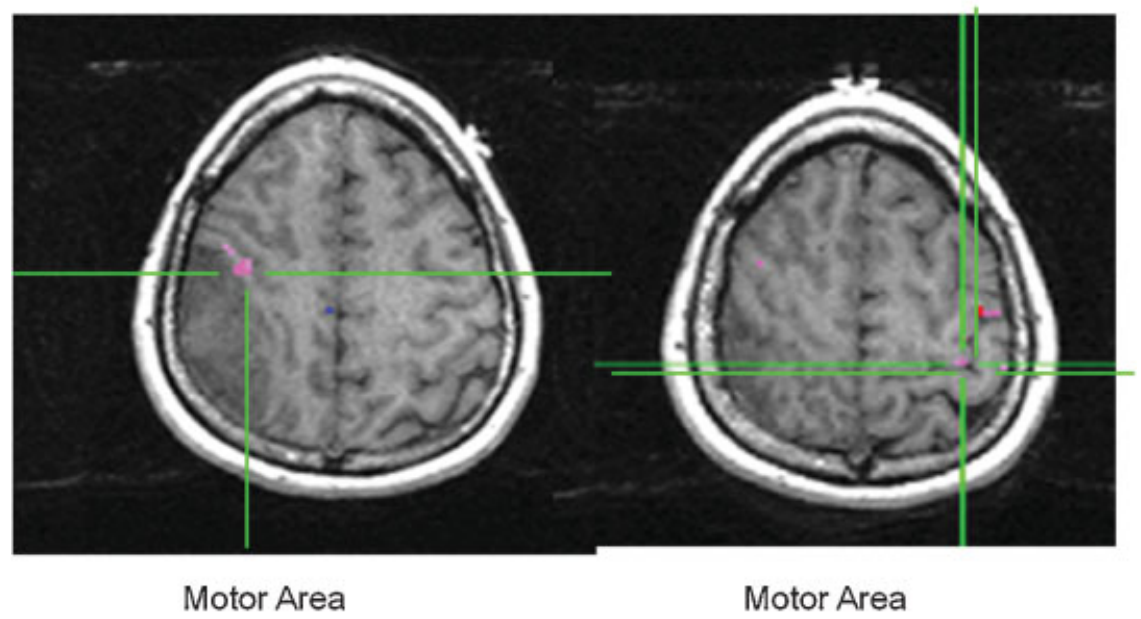

Fig. 1 Functional magnetic resonance imaging (MRI) revealing an anterior compression of motor area (left) and usual topography of motor area (right). 


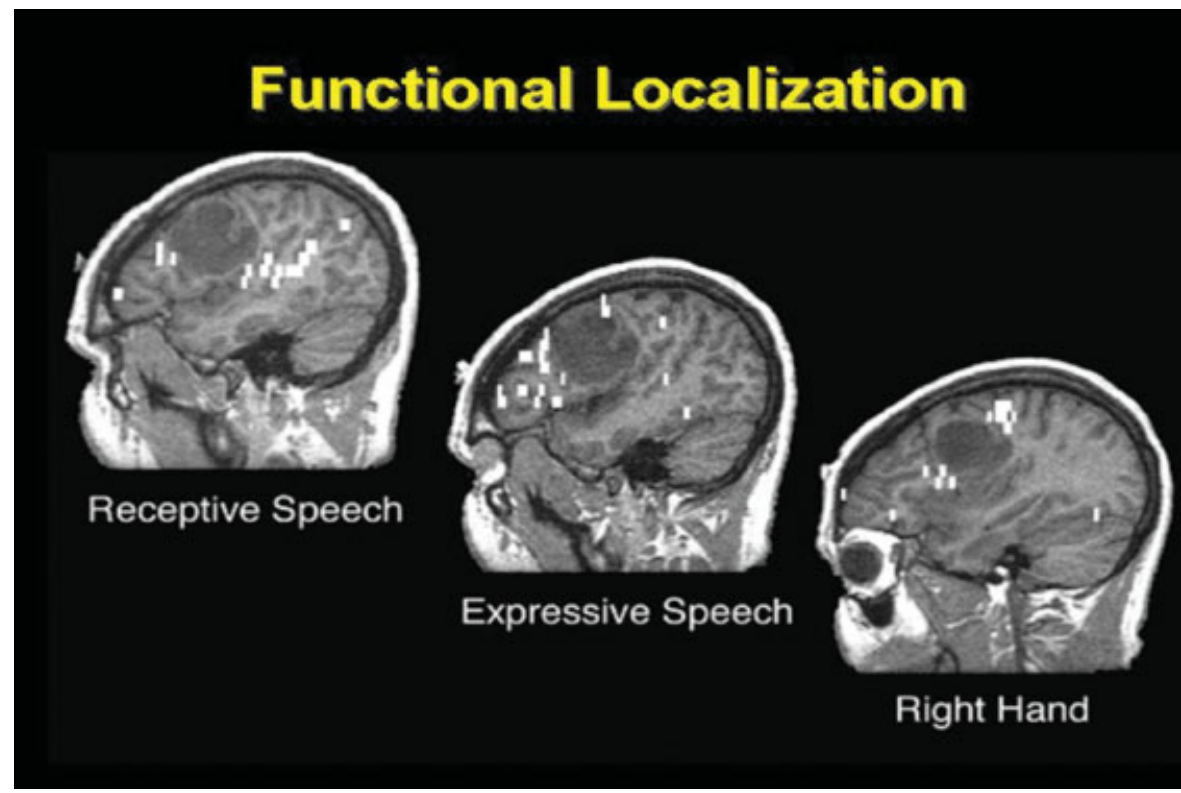

Fig. 2 Functional magnetic resonance to characterize speech areas. Speech areas are highly variable and thus are ideally evaluated during an awake craniotomy. Restrict anatomical landmarks may fail to identify those areas, and additional deficits may happen if awake craniotomy is not performed.

(-Fig. 2). TMS is also a percutaneous method for evaluating eloquent cortex and its role is increasingly being described in literature. Tractography is an MRI tool to evaluate white matter tracts. It is possible to disclose if tumor is within white matter tracts of just dislocating it (-Fig. 3 ). All these measures contribute to increase preoperative planning results.

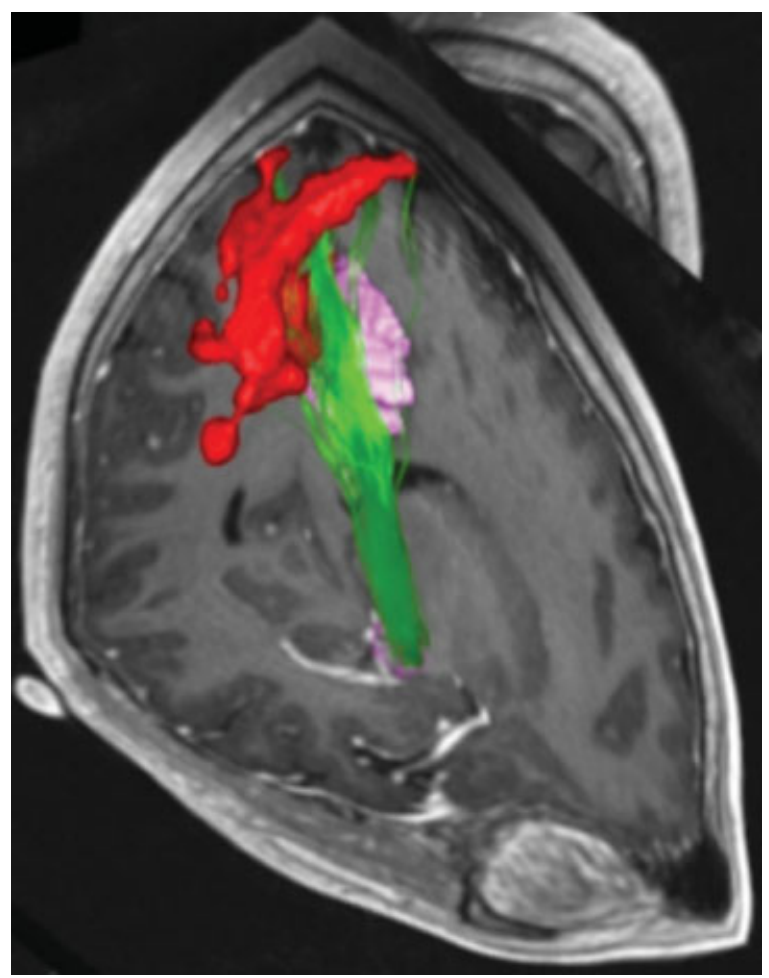

Fig. 3 Illustration of tractography, revealing white matter paths and relation with tumor.

\section{Intraoperative Details}

Performing a qualified anesthesia is the first and most important intraoperative step to a good surgery. Patient may be aware of surgical planning and cooperate during most of the time. Patients with impaired

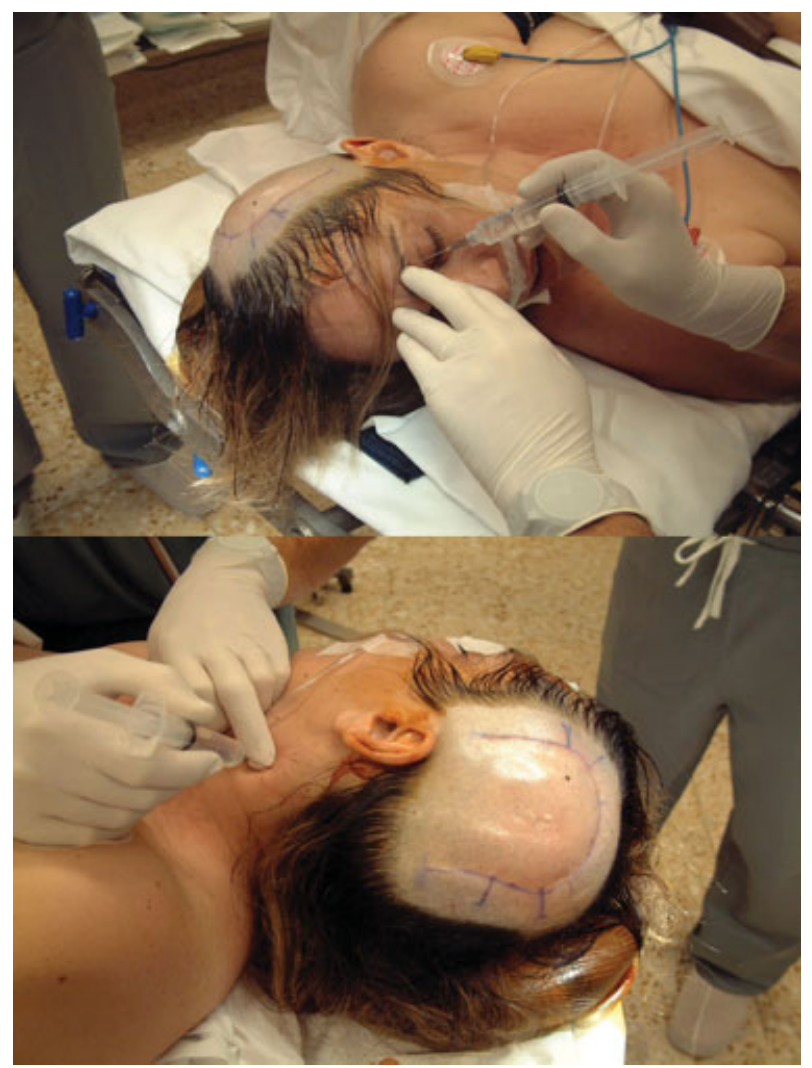

Fig. 4 Patient in lateral decubitus and performing superficial anesthesia. 


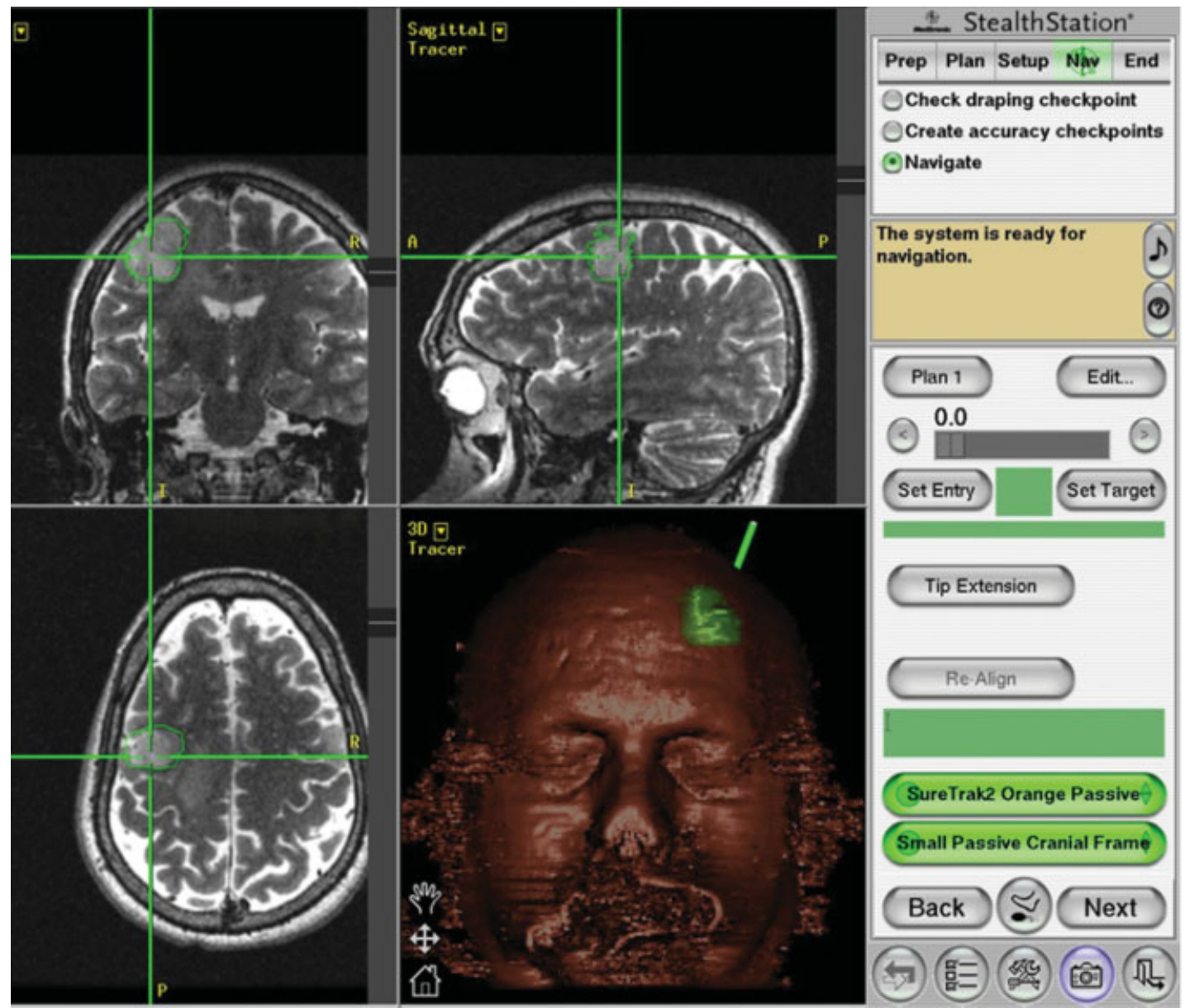

Fig. 5 Neuronavigation example in eloquent area tumor. It provides more precision in localization of lesions and intraoperative evaluation of resection.

consciousness are not ideal candidates for awake craniotomy.

We usually set the patient in a table compatible with intraoperative MR and do not use head holders. In the premedication phase we apply midazolam as an anxiolytic agent. Local analgesia and anesthesia are essential to perform awake craniotomy.

Superficial anesthesia is done with scalp nerve blockade, including bilateral supratrochlear nerves, superficial cervical and great occipital nerve, ensuring whole scalp anesthesia (-Fig. 4). Sedation during exposure is performed with propofol and remifentanil, once drilling and manipulation of skull are not comfortable events to the patient. After complete exposure and beginning of intraoperative stimulation phase, patient is awaken to cooperate.

During stimulation and resection, dexmedetomidine is a useful agent allowing phonoaudiologic/phonotherapist assessment. Intraoperative assessment during surgery includes cortical stimulation, speech, naming, and reading. In case of seizures, cold saline irrigation is performed. Neuromuscular blockers should not be used, once they avoid motor stimulation.

\section{Resection}

During surgery, main goal must be the identification of abnormal tissue and its removal. Auxiliary methods that should be available include transoperative magnetic resonance and neuronavigation. Transoperative magnetic resonance allows evaluation of tumor resection extension in particularly eloquent and deep lesions. Neuronavigation also ensures better localization before and during surgery; however, it has the limitation of shifting due to cerebrospinal fluid leakage after opening of dura (-Fig. 5).

Invasive stimulation methods include direct cortical stimulation (DCS) and this remains the gold standard for generating maps of motor and language system (-Figs. 6 and 7). Physiologic response may be observed in the corresponding muscles and commonly measured as motor evoked potentials (MEPs).

Sensorial and motor cortex distribution is usually predictable and located in pre- and postcentral gyri. However, once cortical organization for languages is really variable, anatomical criteria are undefined. Therefore, preoperative MRI should not be used to guide surgery in such regions.

With intraoperative application of stimulation techniques, it is possible to minimize eloquent area damage and thus proportionate safe tumor resection. 


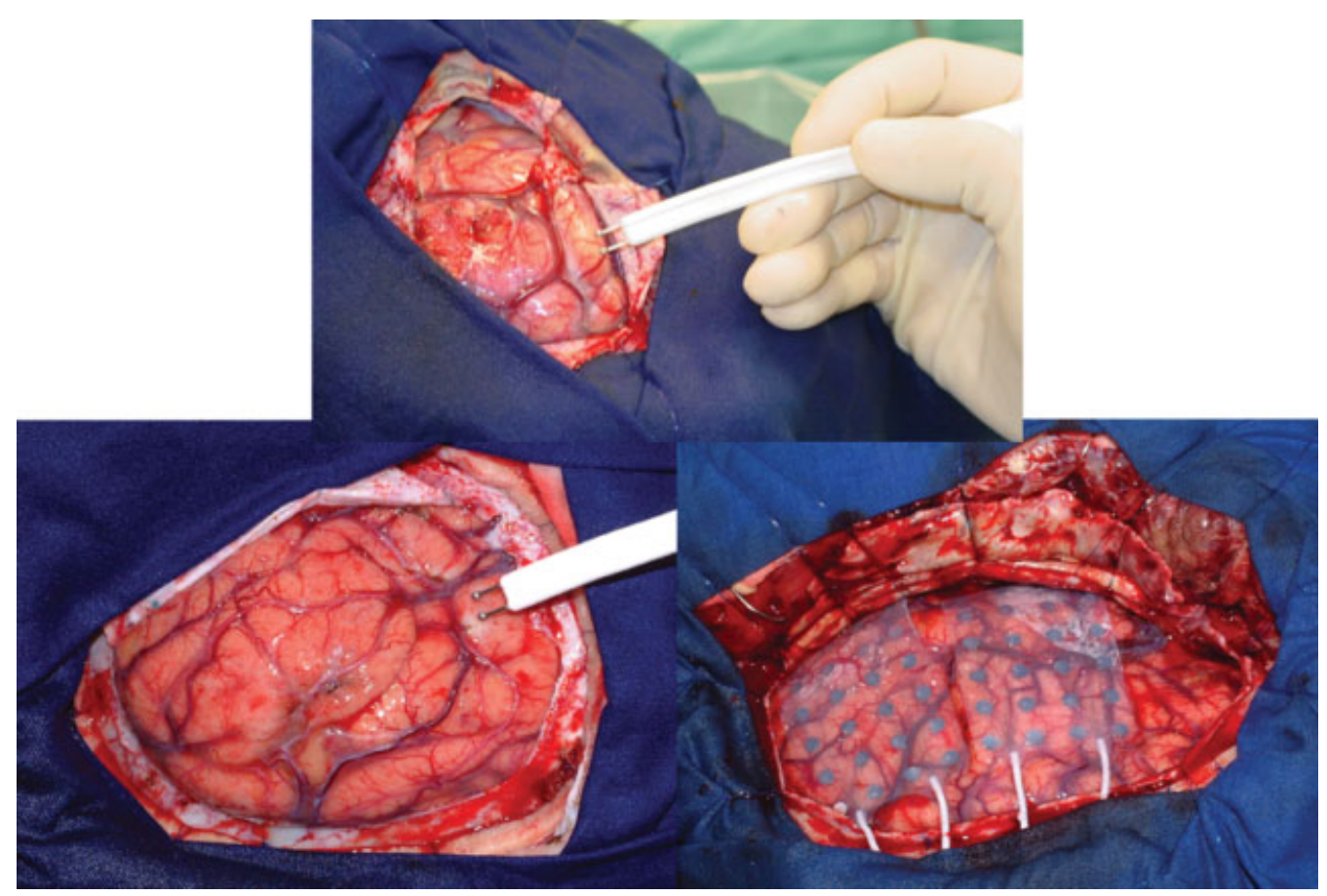

Fig. 6 Cortical stimulation to identify eloquent areas.

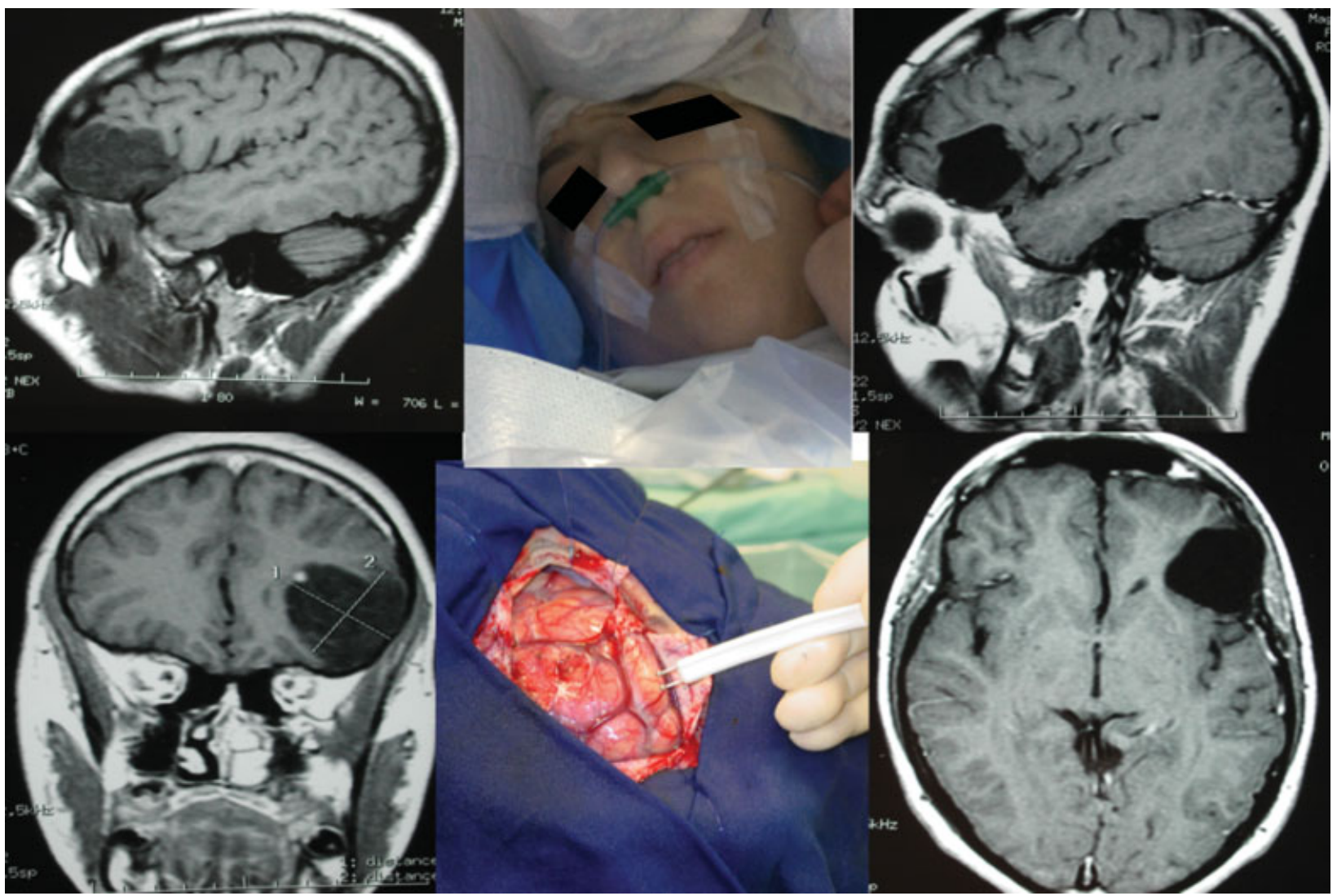

Fig. 7 (Left) Preoperative magnetic resonance (MR) revealing a left frontal tumor. (Middle) Intraoperative assessment and stimulation. (Right) Postoperative MR displaying radical resection without additional deficits. 


\section{Conclusion}

Surgical approach in eloquent area tumors is still a challenge. There must always be a union of maximal resection and minimal additional neurological deficits. For this purpose, anatomical and physiologic knowledge should be combined with technical aspects which allow identification and preservation of eloquent areas.

\section{Conflict of Interest}

Authors declare no conflicts.

\section{References}

1 Satoer D, Visch-Brink E, Smits M, et al. Long-term evaluation of cognition after glioma surgery in eloquent areas. J Neurooncol 2014;116(1):153-160

2 Veeravagu A, Jiang B, Ludwig C, Chang SD, Black KL, Patil CG. Biopsy versus resection for the management of low-grade gliomas. Cochrane Database Syst Rev 2013;4:CD009319

3 Vassal M, Rigau V, de Champfleur NM, Duffau H. Surgical management of diffuse low-grade gliomas associated with other intracranial diseases. Acta Neurochir (Wien) 2014;156(2): 339-347

4 Shields LB, Choucair AK. Management of low-grade gliomas: a review of patient-perceived quality of life and neurocognitive outcome. World Neurosurg 2014;82(1-2):e299-e309

5 Jakola AS, Unsgård G, Myrmel KS, et al. Surgical strategies in lowgrade gliomas and implications for long-term quality of life. J Clin Neurosci 2014;21(8):1304-1309

6 Forst DA, Nahed BV, Loeffler JS, Batchelor TT. Low-grade gliomas. Oncologist 2014;19(4):403-413

7 Hervey-Jumper SL, Berger MS. Role of surgical resection in lowand high-grade gliomas. Curr Treat Options Neurol 2014;16(4): 284
8 Bloch O, Han SJ, Cha S, et al. Impact of extent of resection for recurrent glioblastoma on overall survival: clinical article. J Neurosurg 2012;117(6):1032-1038

9 Orringer D, Lau D, Khatri S, et al. Extent of resection in patients with glioblastoma: limiting factors, perception of resectability, and effect on survival. J Neurosurg 2012;117(5):851-859

10 De Witt Hamer PC, Robles SG, Zwinderman AH, Duffau H, Berger MS. Impact of intraoperative stimulation brain mapping on glioma surgery outcome: a meta-analysis. J Clin Oncol 2012;30(20):2559-2565

11 Frey D, Schilt S, Strack V, et al. Navigated transcranial magnetic stimulation improves the treatment outcome in patients with brain tumors in motor eloquent locations. Neuro Oncol 2014; 16(10):1365-1372

12 Duffau H, Lopes M, Arthuis F, et al. Contribution of intraoperative electrical stimulations in surgery of low grade gliomas: a comparative study between two series without (1985-96) and with (1996-2003) functional mapping in the same institution. J Neurol Neurosurg Psychiatry 2005;76(6):845-851

13 Duffau H. Intraoperative cortico-subcortical stimulations in surgery of low-grade gliomas. Expert Rev Neurother 2005;5(4):473-485

14 Freyschlag CF, Duffau H. Awake brain mapping of cortex and subcortical pathways in brain tumor surgery. J Neurosurg Sci 2014;58(4):199-213

15 Duffau H. Brain mapping in tumors: intraoperative or extraoperative? Epilepsia 2013;54(Suppl 9):79-83

16 Tuominen J, Yrjänä S, Ukkonen A, Koivukangas J. Awake craniotomy may further improve neurological outcome of intraoperative MRI-guided brain tumor surgery. Acta Neurochir (Wien) 2013; 155(10):1805-1812

17 Ius T, Isola M, Budai R, et al. Low-grade glioma surgery in eloquent areas: volumetric analysis of extent of resection and its impact on overall survival. A single-institution experience in 190 patients: clinical article. J Neurosurg 2012;117(6):1039-1052

18 Jiménez de la Peña M, Gil Robles S, Recio Rodríguez M, Ruiz Ocaña C, Martínez de Vega V. Cortical and subcortical mapping of language areas: correlation of functional MRI and tractography in a 3T scanner with intraoperative cortical and subcortical stimulation in patients with brain tumors located in eloquent areas. Radiologia 2013;55(6):505-513 